\title{
ФИЗИОЛОГИЯ СТРЕССОВЫХ СИТУАЦИЙ В СОРЕВНОВАТЕЛЬНОЙ ДЕЯТЕЛЬНОСТИ
}

\section{Алиев Имир Ильяс}

Аннотация. В статье определены физиологические параметры стрессовых ситуаций в зависимости от уровня эмоционального интеллекта. На примере стресса от переживаний во время соревновательной деятельности единоборцев показаны механизмы оценки уровня влияния стресса и разработаны этапы предсоревновательной подготовки спортсменов с учетом фактора стресса.

Annotation. The article defines the physiological parameters of stressful situations depending on the level of emotional intelligence. On the example of stress from experiences during the competitive activity of combatants, the mechanisms for assessing the level of stress influence are shown and the stages of pre-competitive training of athletes are developed, taking into account the stress factor.

Ключевые слова: физиология стрессовых ситуаций, стресогенность соревновательной деятельности, переживания стресса спортсменами, физиологические свойства стресса для соревновательной подготовки, соревнования единоборцев

Keywords: physiology of stressful situations, stressfulness of competitive activity, stress experiences in athletes, physiological properties of stress for competitive training, competition among combatants

Значительное внимание уделяется в научной литературе изучению различных аспектов стресса и его влияния на результат сессии и повседневную жизнь [2-6].

Параметры высшей нервной деятельности спортсменов в ситуации соревновательного стресса [1], равно как электроэнцефалографические корреляты индивидуальных различий [4] и вариабельность сердечного ритма [7], изучены довольно подробно. В равной мере детально исследованы и биохимические показатели студентов в зависимости от соревнований [8-9]. Не менее важно, однако, рассмотреть роль при соревновательном стрессе и адаптации к нему физической активности как коррелятов физиологических параметров и психического состояния. В ряде работ по изучению совладающего поведения и показателей тревожности изучались различия в реализации копинг-стратегий в зависимости от эмоционального интеллекта [9].

Не вызывает сомнения тот факт, что для максимальной реализации спортсменами своего потенциала на соревнованиях требуется высокий уровень устойчивости к стрессу. Несмотря на уровень подготовки в условиях соревнований далеко не все спортсмены могут показать свои возможности. Спортивные психологи в своей работе со спортсменами и тренерами часто сталкиваются с типичными запросами: на тренировках спортсмен показывает один результат, но как только попадает на соревнования, сбивается, допускает технические ошибки, плохо ориентируется в ситуации, повышается тремор и т.д.

Конечно, степень психического напряжения во время состязаний зависит от опыта выступлений спортсмена, но, как показывает практика, чем выше ранг соревнований, тем сильнее напряжение даже у очень опытных спортсменов [4]. В связи с этим возникает необходимость поиска личностных ресурсов атлетов, с одной стороны, для преодоления соревновательного стресса, с другой - для наращивания спортивных результатов [2, 3]. В качестве одного из таких ресурсов рассматривается эмоциональный интеллект [1]. Он представляет интерес с точки зрения способности атлетов регулировать эмоции и создавать у себя оптимальный настрой, снижая интенсивность нежелательных переживаний, распознавать эмоции товарищей по команде или соперников, для того чтобы играть слаженнее или лучше понимать соперника.

Социальный интеллект как один из ресурсов устойчивости к стрессу, который мы рассматриваем, важен в процессе взаимодействия с членами команды, тренерским составом, администрацией, поскольку позволяет выстраивать отношения наиболее выгодным для спортсмена способом. В процессе спортивной деятельности проявляются специфические особенности личности атлетов в зависимости от их пола. В связи с этим необходим дифференцированный подход к спортсменам разного пола. Данное исследование предпринято для того, чтобы выявить особенности устойчивости к стрессу у мужчин и женщин, занимающихся командными и индивидуальными видами спорта.

В связи со стрессом обычно рассматриваются два базовых понятия: тревога и тревожность [5]. Если тревога трактуется в литературе как эмоциональное состояние близкое эмоции страха, то тревожность - как свойство и как черта характера, которая описывает индивидуальные различия в склонности личности испытывать состояние тревоги. Тревожность рассматривается также как переживание эмоционального дискомфорта и предчувствие грозящей опасности. Это свойство психики активируется в предсоревновательный период и достигает своего пика непосредственно перед проведением решающих спортивных мероприятий.

Так, для спортсменов, принимающих участие в соревнованиях по единоборствам, выработаны копингстратегии, которые должны позволить использовать физиологические признаки стресса как форму проявления агрессии по отношению к сопернику. Однако, переживание поражения может, при этом, сказаться на стрессоустойчивости единоборцев перед следующими соревнованиями, активируя страх поражения. Так почему 
ситуация стресса для некоторых спортсменов является физиологически важной составляющей в системе психологического настроя в непосредственный предсоревновательный период, а для других становится причиной дальнейших поражений?

Система спортивной подготовки содержит разработки по физиологическим показателям, оптимальным для соревнований, которые можно активизировать путем психологического влияния на спортсмена. Принято считать, что люди, занимающиеся спортом и участвующие в соревнованиях, чаще испытывают стрессовые ситуации, поэтому вырабатывают толерантность к стрессу и используют продуктивные копинг-стратегии.

Тревога является связующим элементом между поведением и физиологией, поэтому могут существовать корреляционные зависимости между тревогой и физиологическими параметрами и тревогой и копингстратегиями. Таким образом, для контроля физиологических показателей единоборцев следует использовать модель контроля личностной и реактивной тревожности.

Спортивная деятельность, особенно спортсменов высокой квалификации, весьма часто осуществляется в экстремальных условиях. Важно раскрыть собственный потенциал и быть конкурентоспособным на соревнованиях любого уровня. Стресс следует рассматривать как неспецифический ответ организма на предъявляемые средой требования.

Под термином «неспецифический» мы подразумеваем нехарактерные физические или химические особенности стрессоров и изменения в организме, которые они вызывают (их множество, и они разные). Общим для всех стрессогенных факторов следует считать то, что они порождают необходимость изменяться, проявлять адаптивные реакции и возвращаться к нормальному устойчивому состоянию организма.

Стрессоры могут быть совершенно разными по значению (например, удача и несчастье), но «неспецифичность» заключается именно в одинаковой интенсивности их воздействия. В обоих случаях (при удаче или несчастье) возникает потребность организма в адаптивных изменениях. Поэтому сам по себе стрессогенный фактор не может быть «хорошим» или «плохим», любой из них при соответствующей интенсивности вызывает стресс, т.е. напряжение [4].

Так, считается, что развитие физиологического стресса (обоснованного Г. Селье) осуществляется путем непосредственного влияния стрессогенных факторов на организм. В то же время при психологическом стрессе (предложенном Р. Лазарусом) неблагоприятные факторы воздействуют опосредованно, путем осознания, оценки и формирования отношения личности к данному воздействию.

Важным в осознании спортсменами отмеченного различия является то, что психологический (или эмоциональный) стресс выступает фактором, участвующим в активизации психофизиологических реакций до околопредельных или даже «запредельных» границ, т.е. надиндивидуально, значительно превышая уровень гомеостаза [5]. Более того, осуществляется этот процесс как результат антиципации, интуиции и воспоминаний, основанных на опыте спортсмена, основанном на перенесении им подобных условий деятельности.

Следовательно, не нужно противостоять чему-либо, воспринимать предстоящие события как угрозу или опасность, важно формировать в себе способность пренебрежительного отношения к возможным стрессам. Это позволит улучшить работоспособность в условиях соревнований и тем самым увеличит конкурентоспособность спортсмена.

Однако, если в командных видах спорта преодоление стресса происходит незаметно, так как формируется командный дух и коллективное сознание, то в единоборствах спортсмен чувствует единоличную ответственность за проигрыш. Поэтому влияние физиологических показателей стресса для единоборцев крайне опасно, если не контролировать данные процессы. Поэтому система обеспечения правильного выхода из стресса соревновательной деятельности должна иметь следующую структуру:

1 этап: предсоревновательная подготовка:

- детекция детерминант стрессоустойчивости;

- формирование физиологической готовности к перегрузкам;

- анализ эмоционального интеллекта и его самосознание.

2 этап: соревновательная деятельность:

- использование стрессогенных факторов для активизации физиологических показателей граничных компенсаторных систем;

- создание атмосферы коллективной ответственности за результаты соревнований единоборца (тренеров, медиков, менеджеров и пр.) для активизации уровня ответсвенности за высокий результат и нивелирования возможного посттравматического синдрома поражения или любых его проявлений;

3 этап: послесоревновательный восстановительный период:

- система восстановительных процедур;

- нейтральный активный тренировочный процесс.

Формирование образа изменяющейся и проектируемой опасной ситуации соревнований, активизация духовно-нравственного потенциала и ценностносмысловой сферы, выработка плана и решения участия в данном 
соревновании или выхода из создавшейся угрожающей ситуации совершается подсистемой психического отражения действительности [11-12].

Первично действующие факторы (интеллект, уровень культуры, духовнонравственные позиции) определяют отношение спортсмена к самопожертвованию, риску ради других (общества, федерации, страны). Вот в чем проявляется нравственная позиция спортсмена. Кроме того, они управляют трофико-энергетическими, по сути, физиологическими процессами, обеспечивающими стремительный подъем работоспособности.

Осознанное «пренебрежительное» отношение к стрессфакторам в условиях соревнований повышает успешность спортсмена, увеличивает его работоспособность и способствует развитию положительной конкурентоспособной среды в спортивном сообществе. Достижение высоких результатов выступления спортсмена во многом зависит от выработанной им способности в стрессогенных ситуациях соревнований минимально реагировать на свои эмоциональные проявления и максимально игнорировать осмысление, анализ и размышления об опасности, рискованных действиях, возможном травмировании. Сохранение баланса стрессовой нагрузки и процессов восстановления позволяет повышать уровень конкурентоспособности за счет стабилизации общего состояния спортсменов.

\section{Литература}

ellmann M. Preventing overtraining in athletes in high-intensity sports and stress/recovery monitoring // Scandinavian journal of medicine \& science in sports. 2010. 20. P.95- 102.

icolas M., Vacher P., Martinent G., Mourot L. Monitoring stress and recovery states: Structural and external stages of the short version of the RESTQ Sport in elite swimmers before championships // Journal of Sport and Health Science. 2019. N8. P. 77-88.

лешичева А. В., Самойлов Н. Г. Отношение спортсмена к стрессу, негативным состояниям и его конкурентоспособность в условиях соревнований // Ресурсы конкурентоспособности спортсменов: теория и практика реализации. - 2020. - № 1. - С. 3-5.

елоконь, В. О. Психическая устойчивость к соревновательному стрессу у спортсменов разного пола, занимающихся командными и индивидуальными видами спорта // Актуальные вопросы физической культуры и спорта. - 2020. - Т. 22. - С. 75-91.

ерилова Е.И. Эмоциональный интеллект и копинг-стратегии как регуляторы психического выгорания в спорте высших достижений // Интегративный подход к психологии человека и социальному взаимодействию. - Майкоп, 2015. - C. 98-103.

осенко Ю.М., Берилова Е.И. Личностные и когнитивные факторы стрессоустойчивости спортсменов высокого класса // Вестник Костромского государственного университета им. Н.А. Некрасова. - 2015. - Т. 21. - № 2. - С.

ант Е.Е., Орленко Е.М. Психологические средства восстановления психической работоспособности спортсменов // Физическое воспитание студентов. - 2016. - № 5. - С. 4-10

орская Г.Б., Босенко Ю.М., Распопова А.С. Конструктивность реагирования высококвалифицированных тхэквондистов на стрессовые ситуации: психологические предпосылки // Физическая культура, спорт - наука и практика. - 2010. - № 4. - С. 41-48

льин Е.П. Психология спорта / Серия: Мастера психологии. - СПб: Питер, 2008. - 352 с.

латонов В.В. Перетренированность в спорте // Наука в олимпийском спорте. - 2015. - № $1 . \quad-$ C. 19-34.

ехмейструк Е.А. Взаимосвязь показателей баланса стресс-восстановления и качества жизни у спортсменов / Е.А. Цехмейструк, Н.К. Шалина // Теоретическая и экспериментальная психология. - 2020. - Т. 13. - №1. - С. 70-74. алина Н. К., Цехмейструк Е. А. Баланс стресс-восстановления как ресурс конкурентоспособности спортсменов ина// Ресурсы конкурентоспособности спортсменов: теория и практика реализации. - 2020. - № 1. - С. 154-155. 